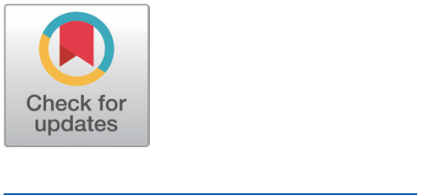

Received: Jun 3, 2020

Revised: Sep 15, 2020

Accepted: Sep 21, 2020

\#These authors contributed equally to this work.

${ }^{*}$ Corresponding author Jinsoo Kim

Department of Bio-Health

Convergence, Kangwon National

University, Chuncheon 24341, Korea.

Tel: +82-33-250-8614

E-mail: Kjs896@kangwon.ac.kr

Copyright ( 92021 Korean Society of Animal Sciences and Technology. This is an Open Access article distributed under the terms of the Creative Commons Attribution Non-Commercial License (http:// creativecommons.org/licenses/by$\mathrm{nc} / 4.0 /$ ) which permits unrestricted non-commercial use, distribution, and reproduction in any medium, provided the original work is properly cited.

ORCID

Hanseo Ko

https://orcid.org/0000-0001-9475-2761

Hwan Ku Kang

https://orcid.org/0000-0002-9984-630X Joseph Moturi

https://orcid.org/0000-0002-0626-0255

Santosh Laxman Ingale

https://orcid.org/0000-0001-6963-3947

Jinsoo Kim

https://orcid.org/0000-0002-9518-7917

\section{Supplementation of enzyme cocktail in chickens diet is an effective approach to increase the utilization of nutrient in wheat-based diets}

\author{
Hanseo Ko ${ }^{1,2 \#}$, Hwan Ku Kang ${ }^{3 \#}$, Joseph Moturi ${ }^{1,2}$, Santosh Laxman Ingale ${ }^{4}$ and \\ Jinsoo $\mathrm{Kim}^{1,2 *}$ \\ ${ }^{1}$ College of Animal Life Sciences, Kangwon National University, Chuncheon 24341, Korea \\ ${ }^{2}$ Department of Bio-Health Convergence, Kangwon National University, Chuncheon 24341, Korea \\ ${ }^{3}$ Poultry Science Devision, Livestock Reseach Development, National Institute of Animal Science, RDA, \\ Pyeongchang 25342, Korea \\ ${ }^{4}$ Advanced Enzyme Technologies, Thane, Maharashtra 400-604, India
}

\section{Abstract}

This experiment was conducted to evaluate the effect of supplementing enzyme cocktail on growth performance, digestibility of nutrients, and monosaccharide concentration in ileum and ceca of broiler chickens fed wheat-based diets. A total of 600 male broilers $(42.26 \pm 1.76 \mathrm{~g}$, 0 day old) were used for 35 days of feeding trial consisting of 2 phases (starter phase from $d$ 0 to 21 and finisher phase from d 21 to 35). Four dietary treatments were prepared based on wheat diets containing four levels of enzyme cocktail supplementation at $0,0.2,0.3$, and $20 \mathrm{~g} /$ $\mathrm{kg}$. Overall, dietary enzyme cocktail supplementation decreased feed conversion ratio (linear $p=0.007$; quadratic $p=0.013$ ) and improved (linear $p<0.05$ ) the apparent ileal digestibility of dry matter (DM), crude protein, and soluble and insoluble non-starch polysaccharides. The apparent total tract digestibility of DM and gross energy were increased (linear $p<0.01$ ) with increasing supplementation levels of the dietary enzyme cocktail. The concentrations of arabinose, xylose, mannose, and glucose in ileal digesta were linearly increased $(p<0.01)$ with increasing enzyme cocktail supplementation levels. In addition, the quadratic effect was observed (quadratic $p=0.046$ ) in mannose concentration of ileal digesta. The concentration of arabinose, xylose, mannose, and galactose in cecal digesta was increased (linear $p<$ $0.05)$ with increasing dietary enzyme cocktail supplementation levels. The supplementation of enzyme cocktail efficiently increased the utilization of nutrients in broiler and there was no adverse effects of high dosage supplementation level.

Keywords: Xylanase, Mannanase, $\beta$-Glucanase, Wheat, Xylose, Arabinose

\section{INTRODUCTION}

Wheat is one of the most common feed ingredients in the poultry diet which contains greater protein content than corn. However, the high non-starch polysaccharides (NSP) in the grain would adversely affect growth performance in poultry. Non-starch polysaccharides are known as anti-nutritional factors 
Competing interests

No potential conflict of interest relevant to this article was reported.

Funding sources

Not applicable.

Acknowledgements

Not applicable.

Availability of data and material

Upon reasonable request, the datasets of this study can be available from the corresponding author.

\section{Authors' contributions}

Conceptualization: Ingale SL, Kim J.

Data curation: $\mathrm{Ko} \mathrm{H}$.

Formal analysis: $\mathrm{Ko} \mathrm{H}$.

Methodology: $\mathrm{Ko} \mathrm{H}$.

Software: Ko H, Kang HK.

Validation: Kim J.

Investigation: $\mathrm{Ko} \mathrm{H}$, Moturi J.

Writing - original draft: Kang HK, Kim J.

Writing - review \& editing: Kang HK, Ingale SL.

Ethics approval and consent to participate The project underwent proper ethical standards and the experiments (KW-1705191) were approved by the Institutional Animal Care and Use Committee of Kangwon National University, Chuncheon, Korea. that create viscous status within the intestinal tract and inhibit the diffusion rate of nutrients and digestive enzymes [1-3]. Arabinoxylan is the major form of NSP in grain [4,5]. In recent decades, various techniques such as enzyme supplementation have been used to decrease the adverse effects of NSP in feedstuffs [6,7].

Poultry is unable to depolymerize the arabinoxylan due to the lack of endogenous arabinoxylan degrading enzyme secretions $[8,9]$. Therefore, arabinoxylan degrading enzymes such as endo$\beta-1,4-x y l a n a s e s$ are commonly used for broiler diets as enzyme supplements [9]. Endoxylanases hydrolyze arabinoxylan into oligosaccharide, which increase the population of beneficial bacteria, leading to a reduction of pathogenic bacteria and improvement of gut health [10-13]. The examination of the concentration of free monosaccharides comprising of NSP in the intestinal tract of broiler chickens would be suggested to evaluate the effects of endoxylanase in broiler chickens and the ability of chickens to degrade NSP in the feed. Kim et al. [6] evaluated the digestibility and concentration of monosaccharides in the gut of broiler for measuring the NSP degradation according to enzyme supplement and feed processing and suggested that the release of monosaccharides in the intestine suggested as a breakdown product of NSP. The use of exogenous enzymes would be one of the ways to utilize the NSPs. Therefore, the present study was developed based on a novel enzyme cocktail for improving the nutrients digestiblity. The aim of this study was to evaluate the effect of dietary enzyme cocktail supplementation in wheat-based diet on growth performance, apparent total tract digestibility (ATTD), apparent ileal digestibility (AID), and monosaccharides concentration in the ileum and ceca of chickens.

\section{MATERIALS AND METHODS}

The protocol for the current study was approved by the Institutional Animal Care and Use Committee of Kangwon National University, Chuncheon, Korea.

\section{Experimental design and animal care}

A total of 600 male broilers (Ross 308, $42.26 \pm 1.76 \mathrm{~g}, 0$ day old) were provided form commercial hatchery (JOIN, Pyeongtaek, Korea) and used for 35 days of feeding trial consisting of 2 phases (starter phase from d 0 to 21 and finisher phase from d 21 to 35). Four treatments were prepared based on wheat and contained four levels of enzyme cocktail supplementation at $0,0.2,0.3$, and 2 $\mathrm{g} / \mathrm{kg}$. Each treatment has ten replications (floor pens) with 15 birds per pen $(2,300 \times 800 \times 1,500$ $\mathrm{mm}^{3}$ ), where the rice hull was covered as litter. Temperature and humidity were controlled by an automatic ventilation system according to the Ross Broiler Management Handbook [14]. Constant light (15 Lux) was offered during the whole experimental period. Birds had ad libitum access to feed and water during the trial.

\section{Experimental diets and enzyme cocktail}

Basal diets were prepared according to the nutrient recommendations of Aviagen [14] for broiler chickens (Table 1). Enzyme cocktail used in the current study was a powder type of enzyme, comprised of mannanase, $\beta$-glucanase, and xylanase (Advanced Enzyme Technologies, Thane, India). The enzyme cocktail was generated through the fermentation of Trichoderma citrinoviride and the final supplement included 7,030,150 mannanase $\mathrm{U} / \mathrm{kg}, 1,890,230 \beta$-glucanase $\mathrm{U} / \mathrm{kg}$, and 39,923,180 xylanase U/kg. To supplement enzyme cocktail, 200, 300, and 2,000 $\mathrm{g}$ of enzyme cocktail were premixed with portions of dietary treatments, respectively, and then the respective premix was mixed to make 1 ton of the whole diets. After the mixing process, the mash diets were conditioned in the barrel covered by heating blocks to a temperature of $75^{\circ} \mathrm{C}$ and then pelleted by a 


\begin{tabular}{|c|c|c|}
\hline & Starter (0-21 d) & Finisher (21-35 d) \\
\hline \multicolumn{3}{|l|}{ Ingredient (\%) } \\
\hline Corn & 44.56 & 46.90 \\
\hline Wheat & 10.00 & 15.00 \\
\hline SBM (45\%) & 37.00 & 28.80 \\
\hline Vegetable oil & 5.47 & 6.37 \\
\hline Choline-Liquid (50\%) & 0.03 & 0.05 \\
\hline L-Lys HCl 78\% & 0.17 & 0.22 \\
\hline DL-Met $100 \%$ & 0.23 & 0.25 \\
\hline L-Thr $100 \%$ & 0.06 & 0.09 \\
\hline Limestone & 1.40 & 1.40 \\
\hline Mono calcium phosphate & 0.39 & 0.31 \\
\hline Salt & 0.31 & 0.30 \\
\hline $\mathrm{NaHCO}_{3}$ & 0.18 & 0.11 \\
\hline Vitamin supplement ${ }^{1}$ & 0.10 & 0.10 \\
\hline Mineral supplement ${ }^{2)}$ & 0.10 & 0.10 \\
\hline Sum & 100 & 100 \\
\hline \multicolumn{3}{|l|}{ Nutritional values } \\
\hline $\mathrm{ME}(\mathrm{kcal} / \mathrm{kg})$ & 3,060 & 3,200 \\
\hline Crude protein (\%) & 22.00 & 19.00 \\
\hline SID Lys (g/kg) & 1.33 & 1.15 \\
\hline SID Met + Cys (g/kg) & 0.91 & 0.85 \\
\hline SID Thr (g/kg) & 0.88 & 0.79 \\
\hline SID Trp $(g / k g)$ & 0.26 & 0.22 \\
\hline Calcium (\%) & 0.80 & 0.76 \\
\hline Digestible phosphorus (\%) & 0.57 & 0.52 \\
\hline
\end{tabular}

${ }^{11}$ The vitamin premix contains the followings per kg of diet: vit.A, $18.000 \mathrm{IU}$; vit.D3, $4.500 \mathrm{IU}$; vit.E, $31.5 \mathrm{IU}$; menadione $\left(\mathrm{K}_{3}\right), 3.6$ $\mathrm{mg}$; thiamin $\left(B_{1}\right), 1.8 \mathrm{mg}$ riboflavin $\left(B_{2}\right), 4.8 \mathrm{mg}$; pyridoxine $\left(B_{6}\right), 3.6 \mathrm{mg}$; cobalamin $\left(B_{12}\right), 0.03 \mathrm{mg}$; niacin $\left(B_{3}\right), 22.5 \mathrm{mg}$; panthothenic acid $\left(B_{5}\right), 15 \mathrm{mg}$; folic acid $\left(B_{9}\right), 0.45 \mathrm{mg}$.

${ }^{2}$ The mineral premix contains the followings per kg of diet: Mn, $86.4 \mathrm{mg} ; \mathrm{Zn}, 72 \mathrm{mg} ; \mathrm{Fe}, 74.6 \mathrm{mg}$; Cu, $6 \mathrm{mg} ; \mathrm{I}, 1.5 \mathrm{mg}$; Co, 0.288 $\mathrm{mg}$; Se, $0.216 \mathrm{mg}$. Enzyme cocktail $0.2 \mathrm{~g} / \mathrm{kg}$ supplementation treatment included 1,398 mannanase U/kg, $340 \beta$-glucanase U/ $\mathrm{kg}$, and 8,024 xylanase U/kg; Enzyme cocktail $0.3 \mathrm{~g} / \mathrm{kg}$ supplementation treatment included 2,158 mannanase U/kg, $542 \beta$-glucanase $\mathrm{U} / \mathrm{kg}$, and 12,084 xylanase U/kg; Enzyme cocktail $20 \mathrm{~g} / \mathrm{kg}$ supplementation treatment included 13,726 mannanase U/ $\mathrm{kg}, 3,870$ $\beta$-glucanase $\mathrm{U} / \mathrm{kg}$, and 79,840 xylanase $\mathrm{U} / \mathrm{kg}$.

SBM, soybean meal; Lys, lysine; Met, methionine, Thr, threonine; ME, metabolizable energy; SID, standardized ileal digestibility; Cys, cysteine; Trp, tryptophan.

220 hp pellet mill (Model; 12 types, Matador, Denmark) with a $2.8 \mathrm{~mm}$ diameter die.

\section{Growth performance}

Body weight (BW; g/bird) and amount of feed were measured at the start and the end of the feeding phases. Body weight gain (BWG; g/bird) was calculated from differences in BW between d 0 and 21 and those between d 21 and 35. The feed intake (FI; g/bird) was calculated from differences between the amount of feed provided initially and the remaining feed depending on the phase feeding (starter, 0-21 d; finisher, 21-35 d). The amount of feed consumtion for 21 to $30 \mathrm{~d}$ was measured and reflected in the calculation of FI during the finisher phase, as two birds ( $30 \mathrm{~d})$ were selected from each pan for the digestibility test. The feed conversion ratio (FCR) was calculated by dividing FI by BWG of each phase. 


\section{Apparent ileal and total tract digestibility}

At $d$ 30, two birds per replicate were selected then each one bird was individually allocated into a metabolic cage $(500 \mathrm{~mm}$ width $\times 400 \mathrm{~mm}$ depth $\times 520 \mathrm{~mm}$ height $)$ for determination of ATTD (\%) of dry matter (DM), crude protein (CP), gross energy (GE), and soluble and insoluble NSP in diets. Diets containing chromic(III) oxide ( $2.5 \mathrm{~g} / \mathrm{kg}$ diets) and water were provided ad libitum. From d 33 to 35, excreta were collected after eliminating feathers and scales. From d 30 to 35, diets containing chromic(III) oxide ( $2.5 \mathrm{~g} / \mathrm{kg}$ diets) were provided to birds in floor pens. At the end of feeding trial (d 35) three birds with similar BW per replicate were slaughtered then digesta samples were collected from ileum and ceca. Collected excreta and digesta samples were lyophilized using freeze dryer for $72 \mathrm{~h}$. Lyophilized excreta and digesta samples were ground using a Wiley laboratory mill (Thomas Model 4 Wiley ${ }^{\circledR}$ Mill, Thomas scientific, Swedesboro, NJ, USA) on $1 \mathrm{~mm}$ screen and stored at $-20^{\circ} \mathrm{C}$ until analysis. The nutrient digestibility was calculated using the following equations: ATTD $(\%)=100-(100 \times[$ chromic(III) oxide in feed \% / chromic(III) oxide in excreta \%] $\times$ [nutrient in excreta \% / nutrient in feed \%]); AID (\%) = $100-(100 \times$ [chromic(III) oxide in feed \% / chromic(III) oxide in ileum digesta \%] × [nutrient in ileum digesta \% / nutrient in feed \%]).

\section{Chemical analysis}

Feeds, excreta, and digesta samples were analyzed for DM (Method 930.15), ether extract (EE, Method 2003.03), ash (Method 942.05), and CP (Method 990.03) [15]. Gross energy of feeds, excreta, and digesta samples were analyzed using a 6400 model bomb calorimetry (Parr Instruments, Moline, IL, USA) and calibration was performed by benzoic acid. Non-starch polysaccharide was estimated according to the method of Englyst et al. [16]. Monosaccharide concentration was determined according to Hosseindoust et al. [17] using gas-liquid chromatography (Agilent 6890 N, Agilent, Santa Clara, CA, USA).

\section{Statistical analysis}

Data were analyzed by ANOVA using the GLM procedure of SAS (SAS Institute, Cary, NC, USA) in a randomized complete block design. Dependent variables consisted of growth and digestibility of nutrient. Individual broiler chickens was experimental unit for digestibility paramenetrs and the average of a pen was experimental unit for growth performance and FI. An orthogonal polynomial contrast test was used to determine the linear or quadratic effects of enzyme cocktail supplementation levels in the diets. Significance and tendency for statistical tests were set at $p<0.05$ and $0.05 \leq p \leq 0.10$, respectively.

\section{RESULTS}

\section{Growth performance}

During the starter phase, BWG showed a tendency to increase (linear $p=0.079$ ) with increasing dietary enzyme cocktail supplementation levels (Table 2). During the finisher phase, FCR tended to be improved (linear $p=0.084$; quadratic, $p=0.065$ ) with increasing dietary enzyme supplementation levels. Overall, dietary enzyme cocktail supplementation improved FCR (linear $p$ $<0.007$; quadratic $p<0.013$ ).

\section{Apparent ileal and total tract digestibility}

Dietary enzyme cocktail supplementation improved (linear $p<0.05$ ) the AID of DM, CP, soluble NSP, and insoluble NSP (Table 3). In addition, the quadratic tendency was observed (quadratic $p=$ 0.074 ) in AID of insoluble NSP. The ATTD of DM and GE were improved (linear $p<0.01$ ) with 
Table 2. Effects of broilers fed diets containing graded levels of enzyme cocktail on growth performance ${ }^{1)}$

\begin{tabular}{|c|c|c|c|c|c|c|c|}
\hline \multirow{2}{*}{ Item } & \multicolumn{4}{|c|}{ Enzyme cocktail $(\mathbf{g} / \mathbf{k g})^{2)}$} & \multirow{2}{*}{ SEM } & \multicolumn{2}{|c|}{$p$-value } \\
\hline & 0 & 0.2 & 0.3 & 20 & & Linear & Quadratic \\
\hline \multicolumn{8}{|l|}{$1-21 d$} \\
\hline BWG (g/bird) & 654 & 696 & 689 & 693 & 13.8 & 0.079 & 0.186 \\
\hline $\mathrm{Fl}$ (g/bird) & 1,035 & 1,078 & 1,042 & 1,060 & 13.2 & 0.522 & 0.370 \\
\hline FCR & 1.59 & 1.55 & 1.52 & 1.54 & 0.03 & 0.207 & 0.449 \\
\hline \multicolumn{8}{|l|}{$22-35 d$} \\
\hline BWG (g/bird) & 1,362 & 1,372 & 1,363 & 1,369 & 41.6 & 0.409 & 0.530 \\
\hline $\mathrm{FI}$ (g/bird) & 2,473 & 2,427 & 2,353 & 2,429 & 67.1 & 0.492 & 0.368 \\
\hline FCR & 1.81 & 1.77 & 1.74 & 1.78 & 0.04 & 0.084 & 0.065 \\
\hline \multicolumn{8}{|l|}{ Overall } \\
\hline BWG (g/bird) & 2,015 & 2,068 & 2,051 & 2,062 & 43.8 & 0.181 & 0.311 \\
\hline $\mathrm{FI}(\mathrm{g} / \mathrm{bird})$ & 3,509 & 3,505 & 3,394 & 3,489 & 67.3 & 0.575 & 0.469 \\
\hline FCR & 1.74 & 1.70 & 1.66 & 1.70 & 0.02 & 0.007 & 0.013 \\
\hline
\end{tabular}

${ }^{1)}$ Each mean represents values from 10 replicates (15 birds/replicate).

${ }^{2)}$ Mannanase $+\beta$-glucanase $+x y l a n a s e$.

BWG, bodyweight gain; FI, feed intake; FCR, feed conversion ratio.

Table 3. Effects of broilers fed diets containing graded levels of enzyme cocktail on digestibility of nutrients ${ }^{1)}$

\begin{tabular}{|c|c|c|c|c|c|c|c|}
\hline \multirow{2}{*}{ Item } & \multicolumn{4}{|c|}{ Enzyme cocktail $(\mathrm{g} / \mathrm{kg})^{2)}$} & \multirow{2}{*}{ SEM } & \multicolumn{2}{|c|}{$p$-value } \\
\hline & 0 & 0.2 & 0.3 & 20 & & Linear & Quadratic \\
\hline \multicolumn{8}{|c|}{ Apparent ileal digestibility (\%) } \\
\hline DM & 65.37 & 66.14 & 69.09 & 68.50 & 0.59 & $<0.001$ & 0.255 \\
\hline $\mathrm{CP}$ & 61.94 & 62.44 & 64.22 & 63.91 & 0.73 & 0.024 & 0.585 \\
\hline GE & 64.78 & 65.19 & 67.09 & 65.61 & 0.68 & 0.158 & 0.175 \\
\hline Soluble NSP & 19.22 & 21.10 & 22.49 & 23.41 & 0.82 & $<0.001$ & 0.558 \\
\hline Insoluble NSP & 17.83 & 19.94 & 21.13 & 20.17 & 0.84 & 0.035 & 0.074 \\
\hline \multicolumn{8}{|c|}{ Apparent total tract digestibility (\%) } \\
\hline DM & 70.23 & 71.06 & 72.17 & 72.36 & 0.42 & $<0.001$ & 0.453 \\
\hline $\mathrm{CP}$ & 66.04 & 67.05 & 67.30 & 67.45 & 0.64 & 0.125 & 0.507 \\
\hline GE & 69.52 & 70.67 & 72.17 & 72.09 & 0.50 & $<0.001$ & 0.227 \\
\hline Soluble NSP & 28.72 & 29.51 & 30.40 & 29.76 & 1.19 & 0.454 & 0.552 \\
\hline Insoluble NSP & 20.48 & 23.95 & 22.04 & 22.74 & 1.02 & 0.293 & 0.183 \\
\hline
\end{tabular}

${ }^{1)}$ Each mean represents values from 10 replicates (15 birds/replicate).

${ }^{2)}$ Mannanase $+\beta$-glucanase + xylanase

$\mathrm{DM}$, dry matter; $\mathrm{CP}$, crude protein; GE, gross energy; NSP, non-starch polysaccharides.

increasing supplementation levels of a dietary enzyme cocktail.

\section{Monosaccharides concentration in ileum and ceca}

The concentrations of xylose, arabinose, mannose, and glucose in ileal digesta were increased (linear $p<0.001$ ) with increasing dietary enzyme cocktail supplementation levels (Table 4). In addition, the quadratic effect was observed $(p=0.046)$ in mannose concentration of ileal digesta. The concentration of arabinose, xylose, mannose, and galactose in cecal digesta increased (linear $p<$ $0.05)$ with increasing dietary enzyme cocktail supplementation levels. 
Table 4. Effects of broilers fed diets containing graded levels of enzyme cocktail on concentration of monosaccharides $^{11}$

\begin{tabular}{|c|c|c|c|c|c|c|c|}
\hline \multirow{2}{*}{ Item } & \multicolumn{4}{|c|}{ Enzyme cocktail $(\mathbf{g} / \mathbf{k g})^{2)}$} & \multirow{2}{*}{ SEM } & \multicolumn{2}{|c|}{$p$-value } \\
\hline & 0 & 0.2 & 0.3 & 20 & & Linear & Quadratic \\
\hline \multicolumn{8}{|c|}{ Ileum (g/kg, DM) } \\
\hline Arabinose & 3.38 & 3.50 & 3.63 & 3.69 & 0.06 & $<0.001$ & 0.602 \\
\hline Xylose & 4.65 & 4.69 & 4.72 & 4.79 & 0.02 & $<0.001$ & 0.637 \\
\hline Mannose & 0.76 & 0.90 & 0.88 & 0.93 & 0.02 & $<0.001$ & 0.046 \\
\hline Galatose & 6.32 & 6.71 & 6.78 & 6.70 & 0.03 & 0.431 & 0.265 \\
\hline Glucose & 3.58 & 3.87 & 3.97 & 4.06 & 0.03 & $<0.001$ & 0.359 \\
\hline \multicolumn{8}{|c|}{ Ceca (g/kg, DM) } \\
\hline Arabinose & 2.38 & 2.42 & 2.54 & 2.56 & 0.05 & 0.006 & 0.912 \\
\hline Xylose & 3.03 & 3.15 & 3.53 & 3.51 & 0.09 & $<0.001$ & 0.455 \\
\hline Mannose & 0.60 & 0.69 & 0.75 & 0.73 & 0.04 & 0.011 & 0.110 \\
\hline Galatose & 5.45 & 5.94 & 6.65 & 6.57 & 0.40 & 0.030 & 0.483 \\
\hline Glucose & 2.39 & 2.54 & 2.70 & 2.60 & 0.11 & 0.106 & 0.246 \\
\hline
\end{tabular}

${ }^{1}$ Each mean represents values from 10 replicates (15 birds/replicate).

${ }^{2)}$ Mannanase $+\beta$-glucanase + xylanase

DM, dry matter.

\section{DISCUSSION}

In the present study, dietary enzyme cocktail improved FCR of broiler chickens. Similar studies reported that dietary xylanase and $\beta$-glucanase supplementation in wheat-based diets led to improved performance of broilers, which is associated with the viscosity of digesta in the intestine of broiler chickens $[7,8,13]$. Enzyme supplemented to wheat-rye-barley-based diets reduced the viscosity of gut digesta in laying hens, resulting a greater digestibility of DM, fat, and NSP [11]. The FI in the present study was not affected by dietary treatments. These results might relate to the nutrient digestibility of diets. It may be associated with the point that the increase of nutrient digestibility caused by the effect of the enzyme cocktail probably improved the FCR.

Dietary enzyme cocktail supplementation improved AID of DM, CP, and both soluble and insoluble NSP in the present study. As young broiler chickens fed wheat-based diets containing NSP-degrading enzymes such as xylanase and $\beta$-mannanase, digestibility of nitrogen, NSP, fat, and starch in the small intestine increased effectively $[17,18]$. Digestibility of nutrients in diets containing corn distillers dried grains with solubles, which contains a high concentration of NSP, also increased as xylanase was supplemented in diets for broiler chickens [3]. The ATTD of DM and GE were significantly improved by dietary enzyme cocktail supplementation in this study. Significant increases of monosaccharides concentration in intestinal digesta of birds fed diets containing dietary enzyme cocktail were observed in the present study. A similar study reported that the increasing dietary levels of $\beta$-mannanase improved the nitrogen and GE retention, which is associated with the usage of the released NSP monomers such as arabinose, mannose, galactose, and glucose as nutrients [17].

The NSP-degrading enzymes can improve nutrient digestibility by reducing the nutrient encapsulating effects in plant cell walls [1,7]. Monosaccharides such as arabinose, xylose, mannose, glucose, and galactose could be released from the enzymatic reaction on NSP, and high concentration of monosaccharides in intestinal digesta would indicate a high hydrolyzing potential to degrade NSP $[2,6]$. Concentrations of arabinose and xylose were increased in the ileal digesta of broiler fed the diets containing xylanase supplementation [5,7]. In the present study, concertation 
of arabinose, xylose, and mannose in both ileal and cecal digesta were increased with increasing dietary enzyme cocktail supplementation levels, glucose, and galactose concentrations also were high in ileal and ceca digesta, respectively. These results supported that the enzyme cocktail supplementation increased the degradation of NSP to increase the release of main NSP monomers including arabinose, xylose, and mannose in the ileum and ceca. In the current study, the linear effect of enzyme cocktail supplementation levels was shown remarkable in the digestibility test, but no quadratic effects was found. It would support that a high dose of enzyme cocktail had not any adverse effects in growth performance and nutrients digestibility. Therefore, the increase of some monosaccharides of intestinal digesta in the current study would be implied that the dietary supplementation of the enzyme cocktail effectively degraded the NSP of the broiler diets.

\section{CONCLUSION}

In summary, the supplementation of enzyme cocktail increased the utilization of nutrients without any advers effects of high supplementary dose. Therefore, the supplementation of the current enzyme cocktail would be recommended for broiler chickens fed wheat-based diets.

\section{REFERENCES}

1. O'Neill HVM, Smith JA, Bedford MR. Multicarbohydrase enzymes for non-ruminants. Asian-Australas J Anim Sci. 2014;27:290-301. https://doi.org/10.5713/ajas.2013.13261

2. Esmaeilipour O, Shivazad M, Moravej H, Aminzadeh S, Rezaian M, Van Krimpen MM. Effects of xylanase and citric acid on the performance, nutrient retention, and characteristics of gastrointestinal tract of broilers fed low-phosphorus wheat-based diets. Poult Sci. 2011;90:1975-82. https://doi.org/10.3382/ps.2010-01264

3. Liu N, Ru YJ, Tang DF, Xu TS, Partridge GG. Effects of corn distillers dried grains with solubles and xylanase on growth performance and digestibility of diet components in broilers. Anim Feed Sci Technol. 2011;163:260-6. https://doi.org/10.1016/j.anifeedsci.2010.11.004

4. Mohammadi Gheisar M, Hosseindoust A, Kim IH. Effects of thermo-resistant non-starch polysaccharide degrading multi-enzyme on growth performance, meat quality, relative weights of body organs and blood profile in broiler chickens. J Anim Physiol Anim Nutr. 2016;100:499-505. https://doi.org/10.1111/jpn.12387

5. Barekatain MR, Antipatis C, Choct M, Iji PA. Interaction between protease and xylanase in broiler chicken diets containing sorghum distillers' dried grains with solubles. Anim Feed Sci Technol. 2013;182:71-81. https://doi.org/10.1016/j.anifeedsci.2013.04.002

6. Kim JS, Hosseindoust A, Ingale SL, Rathi PC, Lee SH, Choi YH, et al. Effects of diet form and xylanase supplementation in a high maize distillers dried grains with solubles (DDGS) diet on performance, nutrient digestibility and non-starch polysaccharide degradation in broiler. Eur Poult Sci. 2016;80:154.

7. Amerah AM. Interactions between wheat characteristics and feed enzyme supplementation in broiler diets. Anim Feed Sci Technol. 2015;199:1-9. https://doi.org/10.1016/j.anifeedsci.2014.09.012

8. Kiarie E, Romero LF, Ravindran V. Growth performance, nutrient utilization, and digesta characteristics in broiler chickens fed corn or wheat diets without or with supplemental xylanase. Poult Sci. 2014;93:1186-96. https://doi.org/10.3382/ps.2013-03715

9. Bautil A, Verspreet J, Buyse J, Goos P, Bedford MR, Courtin CM. Age-related arabinoxylan hydrolysis and fermentation in the gastrointestinal tract of broilers fed wheat-based diets. Poult 
Sci. 2019;98:4606-21. https://doi.org/10.3382/ps/pez159

10. Choct M, Hughes RJ, Bedford MR. Effects of a xylanase on individual bird variation, starch digestion throughout the intestine, and ileal and caecal volatile fatty acid production in chickens fed wheat. Br Poult Sci. 1999;40:419-22. https://doi.org/10.1080/00071669987548

11. Lázaro R, García M, Araníbar MJ, Mateos GG. Effect of enzyme addition to wheat-, barley-and rye-based diets on nutrient digestibility and performance of laying hens. Br Poult Sci. 2003;44:256-65. https://doi.org/10.1080/0007166031000085616

12. Bedford MR, Cowieson AJ. Exogenous enzymes and their effects on intestinal microbiology. Anim Feed Sci Technol. 2012;173:76-85. https://doi.org/10.1016/j.anifeedsci.2011.12.018

13. Hashemipour H, Khaksar V, Rubio LA, Veldkamp T, van Krimpen MM. Effect of feed supplementation with a thymol plus carvacrol mixture, in combination or not with an NSP-degrading enzyme, on productive and physiological parameters of broilers fed on wheat-based diets. Anim Feed Sci Technol.2016;211:117-31. https://doi.org/10.1016/j.anifeedsci.2015.09.023

14. Aviagen. Ross broiler management handbook. Huntsville, AL: Aviagen; 2014.

15. AOAC [Association of Official Analytical Chemists] International. Official methods of analysis of AOAC International. 18th ed. Gaithersburg, MD; AOAC International; 2007.

16. Englyst H, Wiggins HS, Cummings JH. Determination of the non-starch polysaccharides in plant foods by gas-liquid chromatography of constituent sugars as alditol acetates. Analyst. 1982;107:307-18. https://doi.org/10.1039/an9820700307

17. Hosseindoust A, Lee S, Gook Nho W, Song YH, Shin JS, Ingale SL, et al. A dose-response study to evaluate the effects of $\mathrm{pH}$-stable $\beta$-mannanase derived from Trichoderma citrinoviride on growth performance, nutrient retention, and intestine morphology in broiler chickens. Ital J Anim Sci. 2019;18:147-54. https://doi.org/10.1080/1828051X.2018.1500872

18. Kim JS, Hosseindoust A, Ju IK, Yang X, Lee SH, Noh HS, et al. Effects of dietary energy levels and $\beta$-mannanase supplementation in a high mannan-based diet during lactation on reproductive performance, apparent total tract digestibility and milk composition in multiparous sows. Ital J Anim Sci. 2018;17:128-34. https://doi.org/10.1080/1828051X.2017.1345663 